\title{
The effects of polycyclic aromatic hydrocarbons and heavy metals on terrestrial annelids in urban soils
}

\author{
Václav Piž $\left.\right|^{(1)}$, Jiří Schlaghamerský(2) and Jan Tríska(3) \\ (1)Institute of Soil Biology, Biology Centre AS CR, Na Sádkách 7, CZ-370 05, České Budějovice, Czech Republic. E-mail: pizl@upb.cas.cz \\ (2) Masaryk University, Department of Botany and Zoology, Faculty of Science, Kotlářská 2, CZ-611 37, Brno, Czech Republic, E-mail: jiris@sci.muni.cz \\ (3) Institute of Systems Biology and Ecology AS CR, Laboratory of Analytical Chemistry, Branišovská 31, CZ-370 05, České Budějovice, Czech \\ Republic, E-mail: triska@usbe.cas.cz
}

\begin{abstract}
The effect of soil contamination by polycyclic aromatic hydrocarbons (PAH) and heavy metals on earthworms and enchytraeids was studied in urban parks, in Brno, Czech Republic. In spring and autumn 2007, annelids were collected and soil samples taken in lawns along transects, at three different distances $(1,5$ and $30 \mathrm{~m})$ from streets with heavy traffic. In both seasons, two parks with two transects each were sampled. Earthworms were collected using the electrical octet method. Enchytraeids were extracted by the wet funnel method from soil cores. All collected annelids were counted and identified. Basic chemical parameters and concentrations of $16 \mathrm{PAH}, \mathrm{Cd}, \mathrm{Cu}$, $\mathrm{Pb}$, and $\mathrm{Zn}$ were analysed from soil from each sampling point. PAH concentrations were rather low, decreasing with the distance from the street in spring but not in autumn. Heavy metal concentrations did not decrease significantly with increasing distance. Annelid densities did not significantly differ between distances, although there was a trend of increase in the number of earthworms with increasing distance. There were no significant correlations between soil content of PAH or heavy metals and earthworm or enchytraeid densities. Earthworm density and biomass were negatively correlated with soil $\mathrm{pH}$; and enchytraeid density was positively correlated with soil phosphorus.
\end{abstract}

Index Terms: Enchytraeidae, Lumbricidae, soil pollution.

\section{O efeito de hidrocarbonetos aromáticos policíclicos e metais pesados em anelídeos terrestres de solos urbanos}

\begin{abstract}
Resumo - O efeito da contaminação do solo por hidrocarbonetos aromáticos policíclicos (PAH) e metais pesados em minhocas e enquitreídeos foi estudado em parques urbanos, em Brno, República Tcheca. Na primavera e outono de 2007, os anelídeos foram coletados, e amostras de solo foram retiradas de gramados ao longo de transectos, em três diferentes distâncias $(1,5$ e $30 \mathrm{~m})$ de ruas com muito tráfego. Nas duas estações, foram amostrados dois parques com dois transectos cada um. As minhocas com uso do método do octeto elétrico, e os enquitreídeos foram extraídos das amostras de solo pelo método do funil úmido. Todos os anelídeos coletados foram contados e identificados. Parâmetros químicos básicos e concentrações de $16 \mathrm{PAHs}, \mathrm{Cd}, \mathrm{Cu}, \mathrm{Pb}$ e $\mathrm{Zn}$, de cada ponto de amostragem, foram analisados. As concentrações de PAH foram relativamente baixas, e decresceram na primavera, mas não no outono, com a distância da rua. As concentrações de metais pesados não diminuíram significativamente com o aumento da distância. As densidades de anelídeos não diferiram significativamente entre as distâncias, mas houve tendência de aumento no número de minhocas, com o aumento da distância. Não houve correlação significativa entre o conteúdo de PAH ou metais pesados do solo com as densidades de minhocas e enquitreídeos. A densidade e a biomassa das minhocas foram negativamente correlacionadas ao $\mathrm{pH}$ do solo; e a densidade de enquitreídeos foi positivamente correlacionada ao conteúdo de fósforo no solo.
\end{abstract}

Termos para indexação: Enchytraeidae, Lumbricidae, poluição do solo.

\section{Introduction}

The major groups of pollutants emitted by motor vehicles are heavy metals (HM) and polycyclic aromatic hydrocarbons (PAH). The soil fauna of urban greens is particularly exposed to these pollutants. A number of studies have shown that species richness and diversity of earthworms decreased along a gradient of metal pollution (Pižl \& Josens, 1995; Nahmani \& Lavelle, 2002; Lukkari et al., 2004), and most laboratory ecotoxicity tests or field studies have shown negative effects of metals on survival, growth, feeding activity and reproduction of earthworms (Cikutovic et al. 1993; Khalil et al. 1996; Kula \& Larink, 1998). Several studies have also dealt with heavy metal (HM) effects on enchytraeids in the field, usually in 
regard of pollution by metallurgical plants. However, the reported results are not consistent. Bengtsson \& Rundgren (1982) observed a clear detrimental effect of copper, zink and lead contamination on enchytraeid species diversity, densities and occupation of the organic soil layer; however, Kapusta et al. (2003) did hardly find any direct effect of elevated concentrations of these three elements and cadmium.

Much less is known about the effects of PAH on soil invertebrates. The ability of soil organisms, such as earthworms, to survive in the presence of both carcinogenic and narcotic PAH is reflected by their capacity to transform and excrete such chemicals (Milligan et al., 1986). Several authors reported the negative effect of $\mathrm{PAH}$ on the survival and reproduction of earthworms (Son et al., 2003; Brown et al., 2004; Contreras-Ramos et al., 2006; Eom et al., 2007) and enchytraeids (Sverdrup et al., 2002a, 2002b), as measured in different types of toxicity tests. Nevertheless, Eijsackers et al. (2001) concluded that PAH-contaminated sediments have no significant ecotoxicological impact on earthworms; and Erstfeld \& Snow-Ashbrook (1999) revealed even positive associations of the growth of the earthworm Eisenia andrei with PAH concentrations, in toxicity testing of contaminated industrial soils.

Didden \& Römbke (2001) gave an overview of our present knowledge on the impact of soil contaminants on enchytraeids, pointing out the overall suitability of enchytraeids for monitoring purposes, but also the data deficiency in regard of PAH, the need of combining laboratory and field studies, and the interspecific differences in enchytraeid reactions to pollutants. Achazi et al. (1999) showed Enchytraeus crypticus to be hardly affected by PAH, as to survival and reproduction, but to avoid substrate contaminated by some PAH (fluoranthene) while tolerating others (benzo[a]pyrene). The study of Kobetičová et al. (2007) is probably so far the only one looking at the effect of PAH and HM contamination on enchytraeids in soils exposed to emissions of motor vehicles. In this study, soils were sampled in the field, but their effect was tested in the laboratory using cultures of Enchytraeus crypticus. While PAH concentrations were clearly elevated due to heavy traffic, no clear relationship for heavy metals was found. Toxicity tests did not show any detrimental effect on enchytraeid survival and reproduction.
The objective of our study was to assess the concentrations of PAH and HM in soil of urban parks, and their relationships to soil-dwelling annelid assemblages (earthworms and enchytraeids) in these parks.

\section{Materials and Methods}

The impact of soil pollution on terrestrial annelids was investigated in two public parks in the city of Brno (Czech Republic). Two lawns, both adjacent to a street with high traffic intensity, were selected as sampling sites. Samples were taken in 1,5 and $30 \mathrm{~m}$ distance from the street, in spring and autumn 2007 (two transects per lawn and sampling date). Each sampling point included four adjacent soil cores (each of $17 \mathrm{~cm}^{2}$ working area, $12 \mathrm{~cm} \mathrm{depth)} \mathrm{for} \mathrm{enchytraeid} \mathrm{extraction,} \mathrm{and} \mathrm{one}$ sampling point (working area of $1250 \mathrm{~cm}^{2}$; Worm-Ex III device) for earthworm extraction by the electrical octet method (Thielemann, 1986). Enchytraeids were extracted from the cores for 48 hours by the wet funnel method without heating (Römbke et al., 2006). The obtained specimens were counted and identified alive. For enchytraeids, the data for the four soil cores, taken at a given sampling point and date, were pooled. The number of replicates used for further analysis was the same for both annelid taxa (four sampling points per distance and date, half of those in one park and half in the other).

Two sets of soil samples were taken from each sampling point using Kopecky soil sample rings to analyse basic chemical parameters and PAH and HM contents. The contents of sixteen polycyclic aromatic hydrocarbons (N, ACY, ACE, FLU, PHE, AN, F, PY, B(a)A, CH, B(b)F, B(k)F, B(a)P, I(123cd) $\mathrm{P}, \mathrm{D}(\mathrm{a}, \mathrm{h}) \mathrm{A}, \mathrm{B}(\mathrm{ghi}) \mathrm{PE})$ and four heavy metals $(\mathrm{Cd}$, $\mathrm{Cu}, \mathrm{Pb}, \mathrm{Zn}$ ) were determined using atomic absorption spectrophotometry.

Worm density and biomass (the latter for earthworms only) and soil concentrations of PAH and HM, at different distances from the street, were compared using ANOVA. The effects of selected environmental parameters on soil annelids were evaluated using multidimensional statistics (Canoco programme).

\section{Results and Discussion}

Four species of earthworms were recorded, the anecic Lumbricus terrestris and the endogeic Aporrectodea caliginosa being highly predominant. 
The proportions of both species were similar at all distances from the street (Figure 1). However, the proportion of Allolobophora chlorotica increased, and that of Aporrectodea rosea decreased slightly, with increasing distance from the street.

In spring, earthworm densities were extremely low, ranging from 0 to 32 individuals $\mathrm{m}^{-2}$. This was probably caused by an unusually dry and warm early spring. In autumn, earthworm density tended to increase from
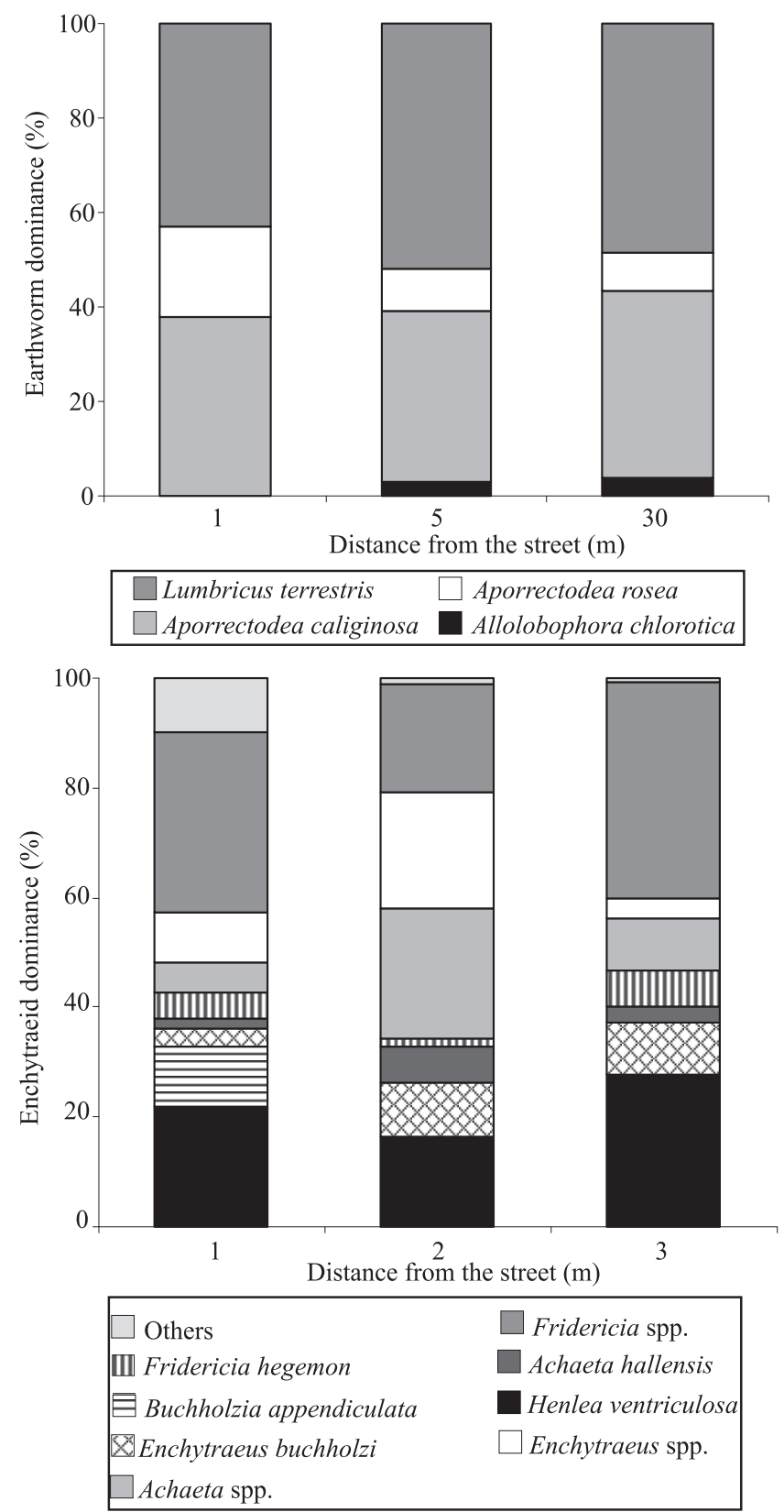

Figure 1. Proportions of individual species of earthworms and enchytraeids, in urban lawns with increasing distance from the street. the street edge towards the centre of the park, with mean values of 116,186 and 216 individuals $\mathrm{m}^{-2}$, at 1,5 and $30 \mathrm{~m}$ distance from the street, respectively (Figure 2). However, the differences were insignificant $(\mathrm{p}=0.48)$.

The enchytraeid community was dominated by Henlea ventriculosa, Buchholzia appendiculata, Enchytraeus buchholzi s.l., three Achaeta species and Fridericia spp., particularly F. hegemon (Figure 1). The r-strategist $B$. appendiculata was present only close to the streets, whereas there was no clear trend
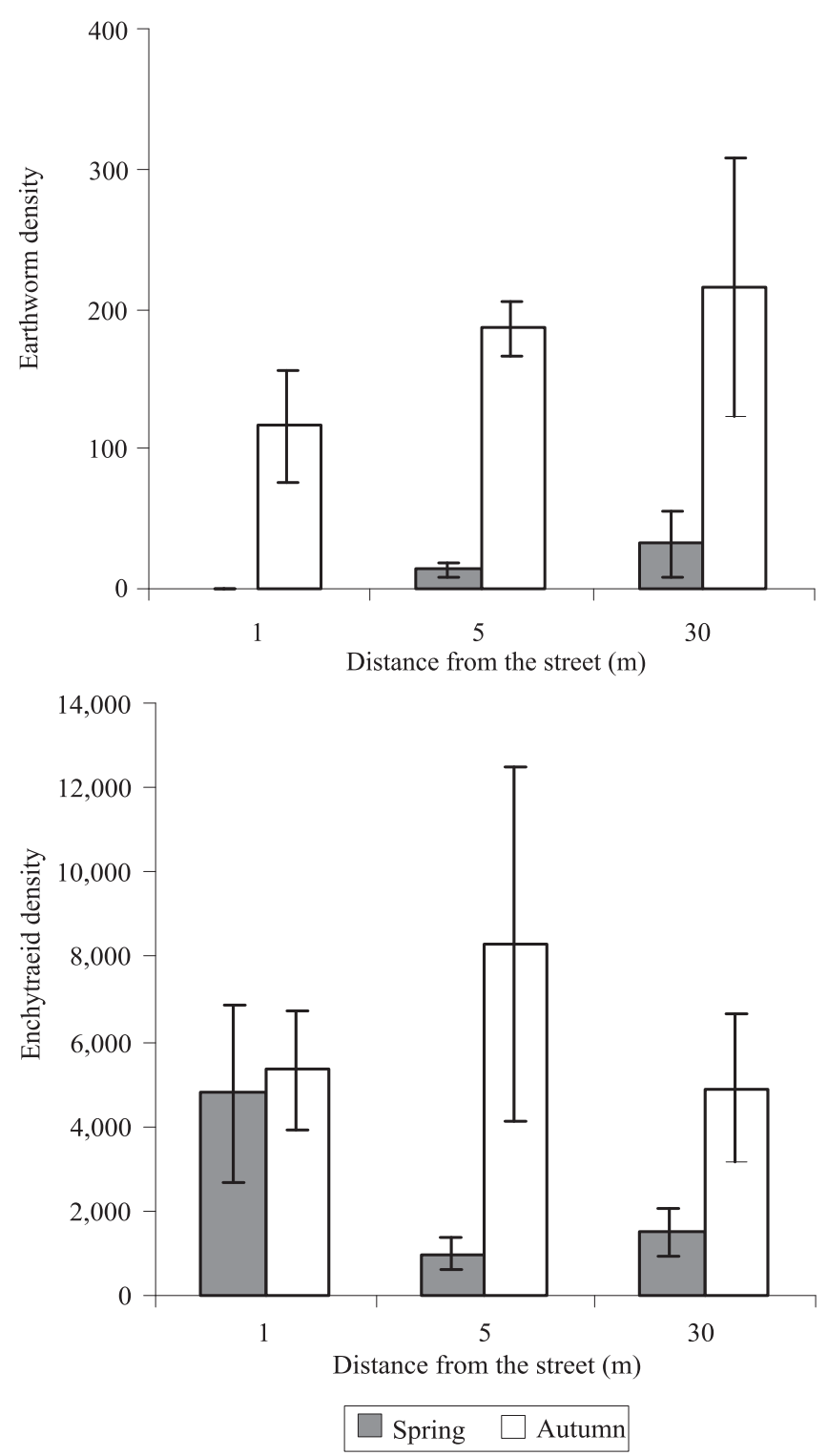

Figure 2. Densities (mean + SE) of earthworms and enchytraeids, in urban lawns with increasing distance from the street. 
in the distribution of the other r-strategist present, E. buchholzi s.l. (including co-geners not identified to species). Of the other enchytraeid species present, only Achaeta species (tolerant to soil compaction) showed some trend, reaching a higher representation in $5 \mathrm{~m}$ distance from the streets.

Enchytraeid densities in spring were very low, with mean values of 4,779, 993 and 1,507 individuals $\mathrm{m}^{-2}$ at the distances 1,5 and $30 \mathrm{~m}$, respectively (Figure 2). The corresponding values for the autumn samplings were 5,331, 8,309 and 4,890 individuals $\mathrm{m}^{-2}$. The differences were not significant, and there was by no means a trend of densities increasing with the distance to the streets.

The content of PAH in soil was relatively low and ranged from 3.2 to $17.65 \mathrm{mg} \mathrm{kg}^{-1}$ in spring, and from 2.9 to $8.1 \mathrm{mg} \mathrm{kg}^{-1}$ in autumn (Figure 3). It decreased with the distance from the street $(p=0.05)$ in spring, but not in autumn. No significant effect of the distance from the street on the contents of HM in soil was recorded. Surprisingly, there was a trend of increasing HM concentrations, in particular that of $\mathrm{Zn}$, from the street edge towards the centre of the lawn (Figure 4).

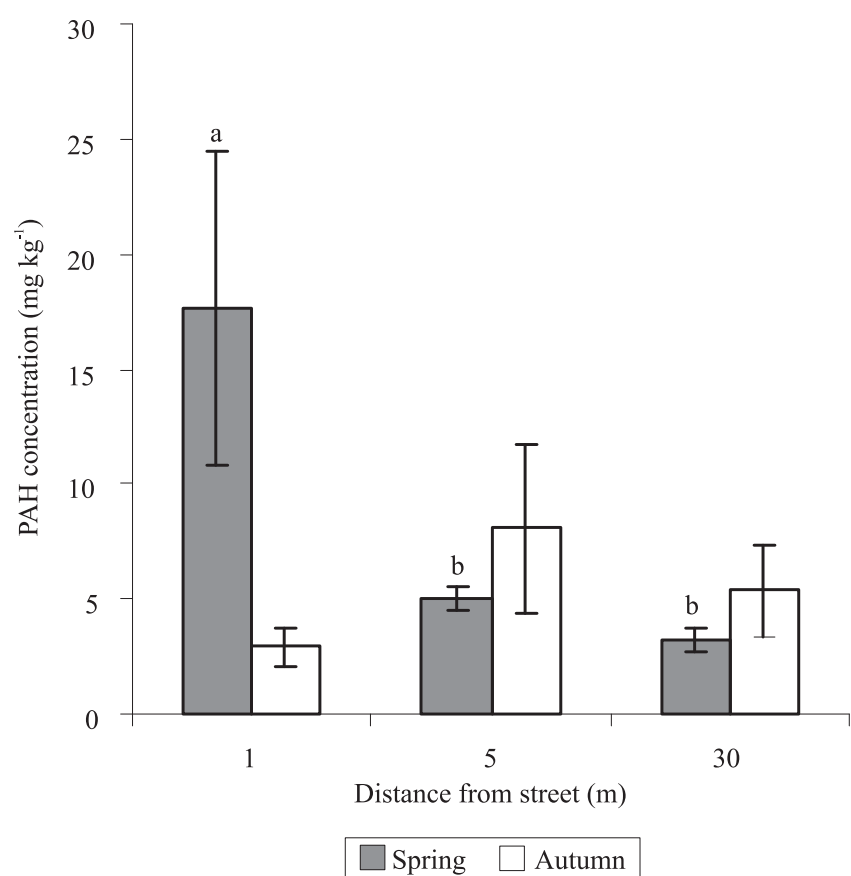

Figure 3. Soil concentrations (mean \pm SE) of polycyclic aromatic hydrocarbons (PAH), in urban lawns with increasing distance from the street; different letters above columns indicate significant differences, by Duncan test, at 5\% probability.
There were no significant correlations between soil content of PAH and the density of earthworms and enchytraeids (Figure 5). This could be explained by the presence of other environmental factors, which could mitigate the often shown toxicity of PAH for earthworms (Brown et al., 2004; Contreras-Ramos et al., 2006). Erstfeld \& Snow-Ashbrook (1999), who found positive associations of soil invertebrate communities with PAH concentrations, in soils of

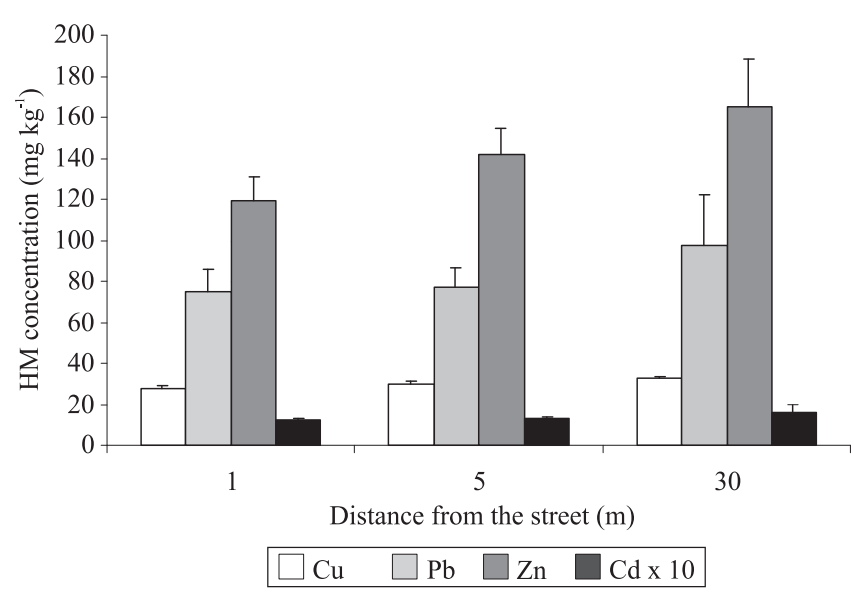

Figure 4. Soil concentrations (mean \pm SE) of heavy metals (HM), in urban lawns with increasing distance from the street.

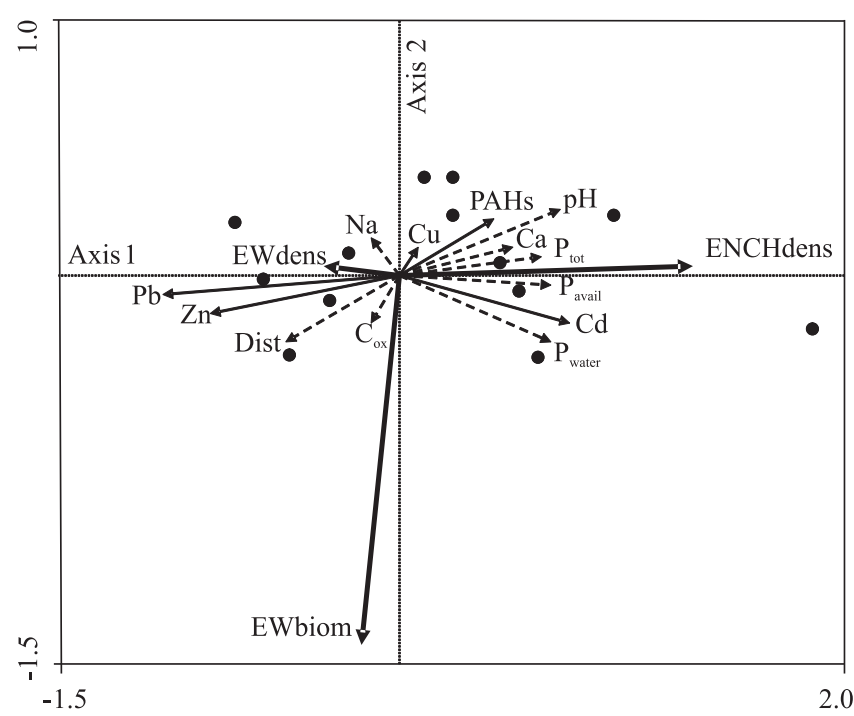

Figure 5. Correspondence analysis triplot (CA, CANOCO programme) of density (EWdens) and biomass (EWbiom) of earthworms and density of enchytraeids (ENCHdens), the distance from the street (Dist), soil contamination (PAH and heavy metals), other soil parameters $\left(\mathrm{C}_{\mathrm{ox}}=\right.$ organic carbon, $\mathrm{P}_{\text {tot }}, \mathrm{P}_{\text {water, }}, \mathrm{P}_{\text {avail }}=$ total, water-soluble and available phosphorus, respectively), and sampling sites (black points). 
industrial sites in Tennessee, USA, suggested that this might be a response to increased populations of soil microflora capable of metabolizing PAH. In addition, enchytraeids seem to be much less sensitive to PAH toxicity than earthworms, as shown by Sverdrup et al. (2002a, 2002b). Also Kobetičová et al. (2007) found no toxic effect of PAH contamination on the tested enchytraeid species. Enchytraeids might avoid soil of higher PAH contamination levels, but this might also depend on the actual compounds present (Achazi et al., 1999; Didden \& Römbke, 2001). Our results do not confirm such avoidance behaviour.

Earthworm density and biomass were negatively correlated with soil $\mathrm{pH}(\mathrm{p}<0.05)$. The density of enchytraeids was positively correlated with total $(p<0.01)$ and available $(p<0.05)$ soil phosphorus. The content of HM in soil did not correlate significantly with the densities of earthworms and enchytraeids. This corresponds with the results by Hobbelen et al. (2006), who did not find direct effects of metal pollution on earthworms, isopods and millipedes, in a contaminated floodplain area in the Netherlands, though metal concentrations in soils were very high. Also Kapusta et al. (2003) did not find any direct effects of heavy metals on enchytraeids. Possible explanations for these results are an adaptation of detritivores to metal pollution, or the presence of other more important factors overruling toxicity effects.

\section{Conclusions}

1. Soil concentrations of polycyclic aromatic hydrocarbons and heavy metals in Brno parks do not decrease with increasing distance from the street.

2. Neither earthworm density or biomass nor enchytraeid density in Brno park lawns increase with increasing distance from the street.

3. Neither earthworm density or biomass nor enchytraeid density in Brno park lawns seem to be affected by elevated concentrations of polycyclic aromatic hydrocarbons or heavy metals in soil.

\section{Acknowledgements}

To the Grant Agency of the AS CR (Project no. IAA600660608); to the Ministry of Education, Youth and Sports of the Czech Republic (Research Plan $n^{\circ}$ MSM0021622416), and to the Academy of Sciences of the Czech Republic (Research Plan $n^{\circ}$ AV0Z60660521).

\section{References}

ACHAZI, R.K.; FRÖHLICH, E.; HENNEKEN, M.; PILZ, C. The effect of soil from former irrigation fields and of sewage sludge on dispersal activity and colonizing success of the annelid Enchytraeus crypticus Westheide \& Graefe, 1992 (Enchytraeidae, Oligochaeta). Newsletter on Enchytraeidae, v.6, p.117-126, 1999.

BENGTSSON, G.; RUNDGREN, S. Population density and species number of enchytraeids in coniferous forest soils polluted by a brass mill. Pedobiologia, v.24, p.211-218, 1982.

BROWN, P.J.; LONG, S.M.; SPURGEON, D.J.; SVENDSEN, C.; HANKARD, P.K. Toxicological and biochemical responses of the earthworm Lumbricus rubellus to pyrene, a non-carcinogenic polycyclic aromatic hydrocarbon. Chemosphere, v.57, p.1675-1681, 2004.

CIKUTOVIC, M.A.; FITZPATRICK, L.C.; VENABLES, B.J.; GOVEN, A.J. Sperm count in earthworms (Lumbricus terrestris) as a biomarker for environmental toxicology: effects of cadmium and chlordane. Environmental Pollution, v.81, p.123-125, 1993.

CONTRERAS-RAMOS， S.M.; ALVAREZ-BERNAL， D.; DENDOOVEN, L. Eisenia fetida increased removal of polycyclic aromatic hydrocarbons from soil. Environmental Pollution, v.141, p.396-401, 2006.

DIDDEN, W.; RÖMBKE, J. Enchytraeids as indicator organisms for chemical stress in terrestrial ecosystems. Ecotoxicology and Environmental Safety, v.50, p.25-43, 2001.

EIJSACKERS, H.; VAN GESTEL, C.A.M.; DE JONGE, S.; MUIJS, B.; SLIJKERMAN, D. Polycyclic aromatic hydrocarbon-polluted dredged peat sediments and earthworms: a mutual interference. Ecotoxicology, v.10, p.35-50, 2001.

EOM, I.C.; RAST, G.; VEBER, A.M.; VASSEUR, P. Ecotoxicity of a polycyclic aromatic hydrocarbon (PAH)-contaminated soil. Ecotoxicology and Environmental Safety, v.67, p.190-205, 2007.

ERSTFELD, K.M.; SNOW-ASHBROOK, J. Effects of chronic low-level PAH contamination on soil invertebrate communities. Chemosphere, v.39, p.2117-2139, 1999.

HOBBELEN, P.H.F.; VAN DEN BRINK, P.J.; HOBBELEN, J.F.; VAN GESTEL, C. A.M. Effects of heavy metals on the structure and functioning of detritivore communities in a contaminated floodplain area. Soil Biology and Biochemistry, v.38, p.1596-1607, 2006.

KAPUSTA, P.; SOBCZYK, L.; ROŻEN, A.; WEINER, J. Species diversity and spatial distribution of enchytraeid communities in forest soils: effects of habitat characteristics and heavy metal contamination. Applied Soil Ecology, v.23, p.187-198, 2003.

KHALIL, M.A.; ABDEL-LATEIF, H.M.; BAYOUMI, B.M.; VAN STRAALEN, N.M. Analysis of separate and combined effects of heavy metals on the growth of Aporrectodea caliginosa (Oligochaeta; Annelida), using the toxic approach. Applied Soil Ecology, v.4, p.213-219, 1996.

KOBETIČOVÁ, K.; HOFMAN, J.; HOLOUBEK, I.; ANDĚL, P. Effect of traffic on survival and reproduction of Enchytraeus crypticus in soils near belt highways. Folia Facultatis Scientiarum Naturalium Universitatis Masarykianae Brunensis: Biologia, v.110, p.211-219, 2007. 
KULA, H.; LARINK, O. Tests on the earthworms Eisenia fetida and Aporrectodea caliginosa. In: LOKKE, H.; VAN GESTEL, C.A.M. (Ed.). Handbook of soil invertebrate toxicity tests. New York: Wiley, 1998. p.95-112.

LUKKARI, T.; TAAVITSAINEN, M.; VÄISÄNEN, A.; HAIMI, J. Effects of heavy metals on earthworms along contamination gradients in organic rich soils. Ecotoxicology and Environmental Safety, v.59, p.340-348, 2004.

MILlIGAN, D.L.; BABISH, J.G.; NEUHAUSER, E.F. Noninducibility of cytochrome P450 in the earthworm Dendrobaena veneta. Comparative Biochemistry and Physiology C, v.85, p.85-87, 1986.

NAHMANI, J.; LAVELLE, P. Effects of heavy metal pollution on soil macrofauna in a grassland of Northern France. European Journal of Soil Biology, v.28, p.297-300, 2002.

PIŽL, V.; JOSENS, G. Earthworm communities along a gradient of urbanization. Environmental Pollution, v.90, p.7-14, 1995.
RÖMBKE, J.; SOUSA, J.-P.; SCHOUTEN, T.; RIEPERT, F. Monitoring of soil organisms: a set of standardized field methods proposed by ISO. European Journal of Soil Biology, v.42, p.61-64, 2006.

SON, A.J.; SHIN, K.H.; LEE, J.U.; KIM, K.W. Chemical and ecotoxity assessment of PAH-contaminated soils remediated by enhanced soil flushing. Environmental Engineering Science, v.20, p.197-206, 2003.

SVERDRUP, L.E.; JENSEN, J.; KELLY, A.E.; KROGH,P.H.; STENERSEN, J. Effects of eight polycyclic aromatic compounds on the survival and reproduction of Enchytraeus crypticus (Oligochaeta, Clitellata). Environmental Toxicology and Chemistry, v.21, p.109-114, 2002.

SVERDRUP, L.E.; KROGH, P.H.; NIELSEN, T.; STENERSEN, J. Relative sensitivity of three terrestrial invertebrate tests to polycyclic aromatic compounds. Environmental Toxicology and Chemistry, v.21, p.1927-1933, 2002.

THIELEMANN, U. Elektrischer Regenwurmfang mit der Oktett-Methode. Pedobiologia, v.29, p.296-302, 1986. 